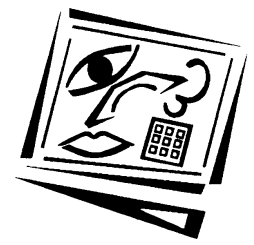

\title{
Signs for learning to perform in a digital environment
}

\author{
J. Ola Lindberg \\ Mid-Sweden University \\ Anders D. Olofsson, Ulf Stödberg \\ Umeå University
}

\begin{abstract}
This article is about learning to perform in a digital environment with specific focus on online higher education. In the article, an online higher educational setting is analysed from a hermeneutical approach, using the learning sequence model suggested by Selander (2008) as a theoretical frame. The institutional framing, used as an empirical example, is a Swedish online higher education course. Based on the course presentation in the course study guide, the course curricula, and the course evaluation, the setting for this article is considered as a case (Stake, 1995; Yin, 2003). The analysis of the setting and course design, in terms of objectives and aims, assessment, and social software used in the course, is focused on the signs as design for learning and on the performative aspects of these intentions. In the final section some issues and questions in relation to designing for learning in online higher education are raised.
\end{abstract}

\section{Introduction}

Higher education is changing rapidly. From being almost exclusively a matter of on campus education, online education is today an educational mode that attracts a vast number of students, students who often seem to come from different walks of life (Olofsson \& Lindberg, 2007). In Sweden, approximately 101,000 students are currently involved in online higher education, which is almost $26 \%$ of the total number of students enrolled in higher education (Swedish National Agency for Higher Education, 2008). It could be said that this large number of students is, at least to some extent, due to technological developments (e.g. the Internet) that enable increased possibilities to participate in higher education, but it is due also to development of tools for conducting education, such as learning mangagement systems (LMS) and ways of organising higher education, for example online communities.

What also seems to have changed rapidly during the last years is our theoretical understanding of this educational mode. These changes shed light on both students' learning and how teaching could be organised to meet these new insights (Harasim, 2002). This can be described as a move away from a view of teaching as teachers' transmission of knowledge, towards a view where students through active participation and in collaboration construct their knowledge of the content area (Jonassen, 2002).

Among these changes, however, there is one element of higher education that, in particular and regardless of theoretical ideas or educational mode, continuously seems to be in need of careful attention and consideration - the element of assessment. For a 
student to earn a higher education degree, she or he is assessed many times. Within the European Union, the question of learning and its relation to assessment has gained increased interest due to the Bologna process. Especially the introduction and use of learning outcomes seem to be a key catalyst for educational change (Bologna Working Group on Qualifications Frameworks, 2004). Learning outcomes seems to mark a shift from teaching to learning - from a teacher centred to a student centred organisation of higher education. In other words:

Learning outcomes statements are typically characterised by the use of active verbs

expressing knowledge, comprehension, application, analysis, synthesis and

evaluation, etc. (Bologna Working Group on Qualifications Frameworks, 2004, p. 18).

This article analyses online higher education, an educational practice buffeted by these changes. Firstly, a comment on the emphasis of a social dimension in teaching and learning is provided, combined with some aspects of the evolution of both Web 2.0 (see for example O'Reilly, 2005; Alexander, 2006) and social software that today seem to be present in the agenda for organising and conducting online higher education. Secondly, some present and emerging theoretical directions of assessment are put forth and discussed. Thirdly, an online higher educational setting is analysed using the learning sequence model suggested by Selander (2008) as a theoretical frame, an analysis beginning from a hermeneutical approach (e.g., Gadamer, 1989; Vattimo, 1997). The institutional framing, used as an example, is a Swedish online higher education course delivered in a distance education mode. Based on the course curricula, course study guide, and course evaluation, the setting is in this article considered a case (Stake, 1995; Yin, 2003). The analysis of the setting and course design, in terms of objectives and aims, assessment, and social software used in the course, is focused in terms of signs of designs for learning and on the performative aspects of these intentions. In order to provide an account of how these were perceived within the setting and course design, the students' course evaluations, are viewed in relation to the desired learning outcomes.

\section{Learning, participation and the social dimension in online higher education}

When reading and reviewing present research literature and theory on how people learn and make meaning, one of the most apparent changes over time is the increased interest in the social dimension of learning (Balacheff, Ludvigsen, de Jong, Lazonder \& Barnes, 2009). This interest seems above all to be present in research literature written in the last two decades. Jonassen \& Land (2000) put forth that the change is due to a shift from a so-called traditional model of learning environments, based on transmission, towards an understanding of learning environments as social arenas for knowledge construction, active participation and collaboration (see also Dillenbourg, Baker, Blaye \& O'Malley, 1995). A focus on how a situated social practice brings about learning through participation.

If a similar review is conducted, with specific focus on online higher education and the use of technology for educational purposes, a similar shift appears to have taken place. Moving from a focus on transmission, via a cognitive focus on representation and construction, it seems that a narrower focus on social theories of learning and collaboration is more prominent (Sorensen \& Ó Murchú, 2006; Willis, 2009). 
Online higher education can today be seen as enhancing participation with others in a social arena (Friesen, 2009). Through the Internet, the idea of a learning environment can be realised in a virtual mode, and at the same time be used with the explicit purpose of providing a social dimension in higher education online (Lindberg \& Olofsson, 2008; Olofsson \& Lindberg, 2006). It seems to provide via asynchronous (Paulsen, 2003) and synchronous (Hrastinski, 2007) participation rich and flexible possibilities for learning through processes of meaning-making within a social context (Zumbach, Schwartz, Seufert \& Kester, 2008).

There seems also to be a connection to research investigating the concept of community within education (see Reigeluth, 1999; Sergiovanni, 1999). Teaching and learning in the extended deployment of the learning environment, participation and information and communication technologies (ICT), seems possible to describe in terms of research concerned with the question of how learning environments can foster the building and upholding of an online learning community (OLC) on the Internet (Lindberg \& Olofsson, 2010).

The theoretical ideas behind the concept of OLC seem to originate from Wenger's (1998) social theory of learning in which it is stressed that a learner continuously must be provided with opportunities to participate in a community in order to learn, create meaning and understanding. It is said that meaning depends on social, relational and temporal aspects and is the product of a shared process of negotiation. OLCs in online higher education are said to encourage students being their own co-teachers (Sieber, 2005), and that they learn with and from each other (Palloff \& Pratt, 2005). The development of Web 2.0 which facilitates design for active participation seems in addition to be powerful for the practice of online higher education (Olofsson \& Lindberg, 2011).

As can be seen, there is a developing body of research into participation in online higher education, but some further questions can be raised. For instance, is learning and participation always possible to design? Will online higher education students let themselves be designed to participate? Is it necessary to reflect upon the practice of assessment when designing for learning? Will the design for active participation teach students how to represent and perform successfully in an educational context framed by the practice of assessment? Will students adjust to learning in a context of learning from peers? We return to these aspects in the final section of this article.

The next section will further deal with the evolution of Internet and the development of Web 2.0 - from a presentation oriented and information driven conception, towards a participant driven conception.

\section{Web 2.0 and social software: A brief description}

In the last decade, many online higher education courses have been adapted for presentation on a learning management system (LMS). Although practices with these systems often are highly text-orientated, they have enabled the opening of a social dimension of learning that was previously lacking. However, the text-based practices they have spawned have tended to focus on individual inputs and outputs rather than on social exchanges. The LMS provided a way to adapt the ordinary learning environment to a digital interface, allowing for student participation regardless of space and time constraints they may face. Nevertheless, education still appears often to 
be designed on the basis of the same assumptions and on the same metaphor of learning, on acquisition and reproduction of text. The presentation-oriented and information-driven learning environment tends to focus on content, access and download, a fixed design, being teacher directed, and with limited ways of providing feedback in relation to, for example, student assessments (Sinclair, McClaren \& Griffin, 2006).

One recent trend in online higher education builds on the advancement of the Internet from being just a place to download material towards a place where people meet, socialise and upload material, self publish blogs and media collections, electronic portfolios, podcasts, vodcasts, and use social networking software and sites (Olofsson, Lindberg \& Stödberg, 2011; Porter, 2006). Often characterised as 'Web 2.0', this trend is linked with software that allows social interactions of a completely different kind. With social software, the user can contribute to the content and elaborate upon it. This shift can be conceptualised as a move from a presentation oriented and information driven Web 1.0, towards a participation-driven Web 2.0; a shift that is possible to understand in terms of inviting to participate (Davies \& Merchant, 2009).

Currently, in online higher education, more and more social software is incorporated in the course and program designs, and there are an increased number of articles reporting on successful and productive ways of designing courses using social software to increase and foster student interaction (Beldarrain, 2006). In this move, an upgrade of the learning environment from 1.0 to 2.0 (and even 3.0) is implied. This notion includes a focus on, for example, learning processes, on communication and interaction, on evolving knowledge production and understanding, on sharing, demonstration and providing rich feedback (Sinclair, McClaren \& Griffin, 2006). Such activities in general, and feedback in particular, are highly connected to the practice of assessment, and in the next section, the issue of assessment will be in focus.

\section{Assessment as a practice in transformation within higher education}

Assessment has in various ways and for a long time been a crucial and often debated element in the context of higher education in general (Gibbs \& Simpson, 2004-2005). In his seminal work, Snyder (1971) claimed that what influences students the most is not teaching and learning but assessment. That is, what students do in their studies is mainly influenced by what they think the assessment system will require of them. Rowntree, also in the seventies (1977), put forth similar ideas claiming:

If we wish to discover the truth about an educational system, we must look into its
assessment procedures. What student qualities and achievements are actively valued
and rewarded by the system? (p.1).

In this sense, assessment is the most important feature of a design for learning.

In more recent research concerned with assessment and higher education, a trend towards involving students in the assessment practices seems to have emerged. For example, O'Donovan, Price and Rust (2004) highlight the importance of making the assessment criteria and grades transparent and by doing so simultaneously make it possible to find a way past the student behaviour described by Snyder (1971) and Rowntree (1977). Bloxham and West (2004) have conducted research pointing in the 
same direction. They claim that there is a direct need among students to understand the assessment standards and criteria they face in their studies. Struyven, Dochy and Janssens (2005) put forth that research findings reveal that students' perceptions about assessment significantly influence their approaches to learning and studying. Another emerging trend seems to be that assessment in higher education shall preferably provide rich opportunities for student learning, not student control (Challis, 2005). Formative assessment in higher education seems to be one way to cultivate and provide opportunities for such student learning to take place (Williams, 2008). The use of formative assignments, that continuously provide the students with feedback, make it possible for them to modify their learning activities and improve their understanding (Black \& William, 1998) during a course. Today formative assessment modes such as portfolios, peer assessment and simulations seem rather often to replace or at least complement more summative orientated modes of assessments like essays and multiple-choice exams (Sambell, McDowell \& Brown, 1997; Van den Bergh, Mortelmans, Spooren, Van Petegem, Gijbels \& Vanthournou, 2006).

When focusing on enhancing student learning in higher education, the development and use of ICT and the Internet seems in this matter to embody great potential and expectations about 'e-assessment' in which technology is used in the assessment process seem to be high (JISC, 2007). Interestingly, the uptake seems to vary between countries and educational sectors and a formative assessment approach seems to be most frequently used within the practice of e-assessment (Boyle \& Hutchison, 2009; Boyle, 2007). It is even said that when used in a skilful way e-assessment can contribute to increase the range of what is tested, as well as enhance the validity of assessment systems. Designed for diagnostic and formative purposes e-assessment seems in other words to be valuable in order to foster more effective learning for a wider diversity of learners (JISC, 2007).

When reflecting over research and practice related to assessment and e-assessment, not only an ambition to move away from a knowledge transmission and replication analogy within higher education seems to be present, but also an ambition to enhance more student active forms of assessment. The social dimension of learning seems in other words to be eminent and important. Relating this development to theory, one perspective that often seem to function as framework is social constructivism (see for example Price, O'Donovan \& Rust, 2007; Rust, O'Donovan \& Price, 2005; for research studies conducted within a social constructivist perspective see for example Vygotsky, 1962; 1978, for more thorough elaborations upon the central assumptions of learning). Another theoretical framework that often seems to be drawn upon originates from the work of Wenger (1998) and his concept of community of practice (see for example Price, 2005; Elwood \& Klenowski, 2002). In higher education, at least three things appear to unite these theoretical viewpoints. First, that the learning process is understood as characterised by active participation, collaboration, reflection, multiple perspectives and dialogue. Second, that students participating in a social context or a community in order to learn, make meaning and to enhance understanding, is of importance. Third, the idea that learning is to be understood as the result of a process of negotiation taking place between those involved. All three appear to be important for the challenge to design for productive and student-centred learning in online higher education. 


\section{Research aim}

The aim of this study is to deepen the understanding of the intended meaning-making processes of studying in an online higher education course, and by intended is meant that which is assessed. The assumption is that the institutional framing of a course enables certain meaning-making processes, and the objective is to create one possible understanding of these processes as they are framed by certain institutional settings in objectives and assignments and assessment practices. The use of a case study design is intended to enhance understandings of the particularities of one setting, and thereby point towards a possible understanding with more general implications. In addition, data from the course evaluation is provided as a way of relating the course design to the learning outcomes of the course as perceived by course participants. Using the formal learning sequence model (Selander, 2008), our intention is to specifically analyse signs of designing for learning, as they are presented in the course study guide, learning outcomes and curricula of an online higher education course.

\section{Method}

The overall research design builds on case study methodology (Stake, 1995; Yin, 2003). Case study methodology is considered in research cases where the aim is to provide further understanding of complex social phenomena (Yin, 2003). The rationale for choosing a single case is grounded in Stake (1995). As he puts it, the real business of case studies is particularisation. A single case was chosen to be a unique case, with the potential to be revelatory because of its particularity. Or as Stake (1995) expresses it "The function of research is not necessarily to map and conquer the world, but to sophisticate the beholding of it" (p. 43).

The analyses of the course was carried out using a hermeneutical approach, in which trying to produce an understanding open to further questions is more important than producing an answer claiming to be true (e.g., Gadamer, 1989; Vattimo, 1997). A hermeneutical approach also seemed appropriate in combination with a case study design, as interpretation and case methodology are closely aligned. Stake (1995) declares that a "case study is patient, reflective, willing to see the other view of the

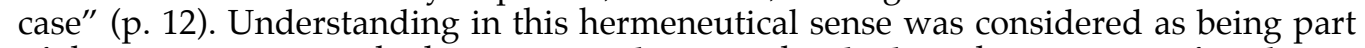
of the interpretation. The hermeneutical approach relied on the concepts of tradition, prejudice and effective history (Gadamer, 1989). Tradition refers to the influence of the past and the repetition that is thereby brought about. Linked to tradition is the concept of prejudice, the already taken for granted aspects of tradition, which makes understanding possible. Effective history is the guiding principle for understanding the human being as already part of a tradition. Within the constraints of historicity, understanding can be achieved through the constant strive to separate prejudices that obstruct further understanding from those which make understanding possible. By making the hidden prejudices of tradition the object of reflection and thereby isolating them and suspending their validity as much as possible, a new or different meaning can emerge. This distancing process is carried out using a theoretical framework for interpretation, i.e. the model provided by Selander (2008).

The framework was used with the intention of limiting the influence of prejudices, and thereby avoiding interpretations to be altogether determined by the researcher's prejudices. The use of the framework separates those prejudices that obstruct understanding from those that make a different understanding possible (Gadamer, 
1989). It produces a gap between those prejudices containing current understandings and the institutional setting that was interpreted, i.e. two horizons through which a different understanding can be accomplished.

The theoretical framework emanates from the view of learning as a meaning-making process described by Selander (2008) and presented in Figure 1. The design of signs and symbols making up the institutional framework of a learning sequence, in this case the settings of an online higher education course, was considered to form a process in which two transformational cycles had to be considered.

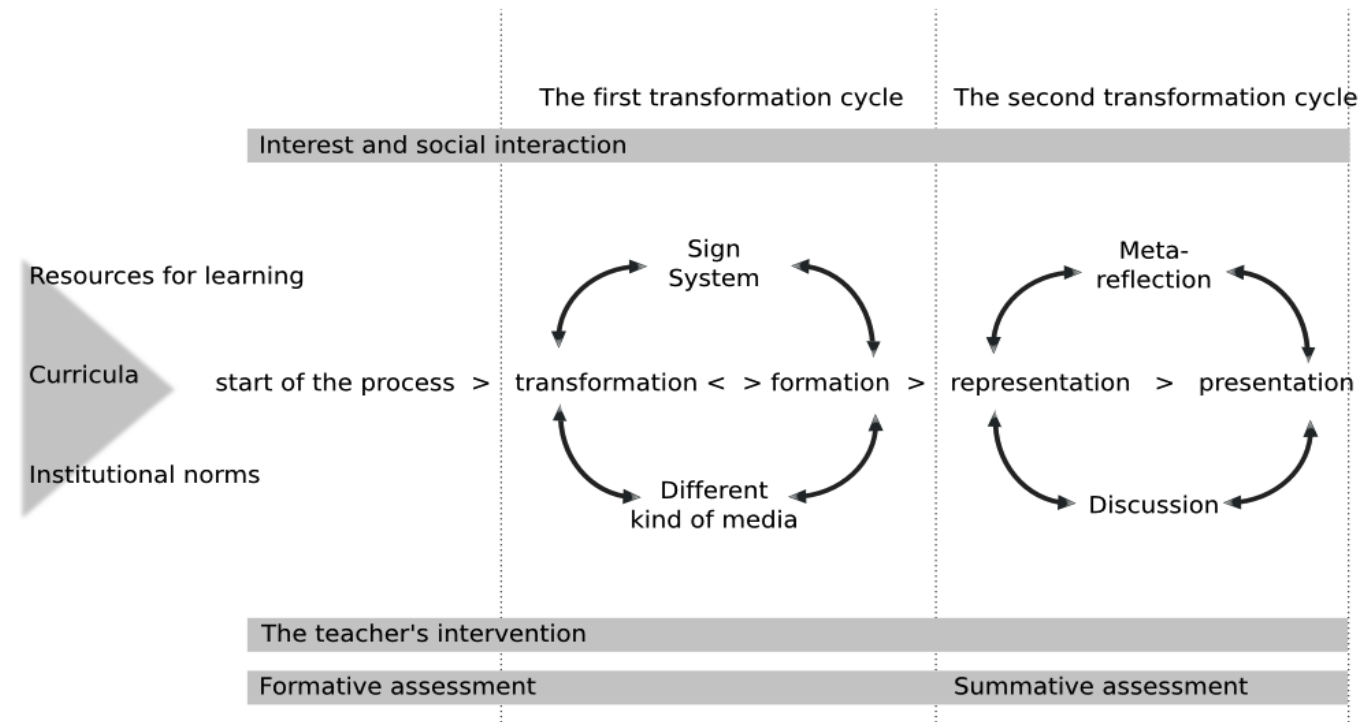

Figure 1: Learning as a meaning-making process conceptualised in the formal learning sequence model (Selander, 2008; translated into English by the authors)

Based on the first cycle, the analysis focused on how the available resources for learning, the curricula and the institutional norms and values could be interpreted and understood to meet student interests. This gave the means for analysing the conditions for the students' meaning-making processes through the signs that were built into the design of the course. The analysis also focused on the social interaction designed for the course and its role in the formative assessment practices, as well as to the conditions for students' meaning-making process as it could take form framed by media and mode; an interpretation of learning and meaning-making as intended representation of the designed intentions of the course.

The second cycle focused the analysis on the conditions for students' learning and meaning-making as a presentation of the intended learning, a presentation which had its starting point in the representation of the learning interpreted in the design of the course. It gave the means to interpret the meaning-making process intended in the social interaction and practice of the course, in terms of discussions and meta-reflection and its role in the summative assessment practices. This led the analysis to interpretations of the signs as a design for learning to perform. In the analysis the course study guide and curricula are regarded as signs, designed for learning to perform in a digital environment. 
In addition to data in the form of written documents including the course study guide and curricula, data from the course evaluation has also been used (see further Rasmusson, Sahlin \& Sundgren, 2008). The evaluation focused in particular on the students use of technologies, and therefore also on the design of the course. It was conducted between the months of June and August 2008. The evaluation was considered suitable to use as a reference point for the students' views on the outcomes of the course. Both focus group interviews and questionnaires, initial and follow up, were used in the evaluation providing both quantitative and qualitative measures. The areas included in the evaluation are closely aligned with the learning sequence model, providing both initial expectations on the course, interests and social interactions, more in depth responses to the resources and setting of the course, as they were experienced by the students, as well as experiences related to the learning outcomes of the course and the assignments. In total 24 students participated in the course from the start, 19 finishing it. The results from the evaluation will be provided in a synthesis of the overall evaluation, that is it provides the essence of what the students gave words for in the group interviews and the questionnaires. This will then by viewed in relation to the learning outcomes of the course, as they can be said to have been reached by the students.

\section{A short contextualisation of the course}

In this section, the intention is to give a brief overview of the signs for learning as they were described in the course study guide and curricula together with the resources made available. The institutional framing is a Swedish online higher education course delivered in a distance education mode using the Internet. The aims of the course state that the students should develop their ability to use ICT and media as a pedagogical tool. Further, the course would integrate in its design practical applications with theoretical aspects of the use of ICT, and the students would, for example, use digital video, computer based communication, web publishing, digital sound and imaging, blogs and podcasts, integrated with work on research literature on the use of ICT in education. In the learning outcomes of the course it was stated that the students at the end of the course:

- should show ability to apply ICT and media as a pedagogical tool in their own practice

- should be able to plan for and create digital videos for a pedagogical practice

- should show ability to critically examine ICT and media

- should show ability to plan for and publish materials on the web

- should know about copyright issues and issues concerning personal material

- should know about research and technological development within the field.

The course ran for 10 weeks at $50 \%$ of full time during the summer of 2008 . The students met for two days at the beginning of the course for information, lectures, workshops and group work. They then worked on the course assignments, individually and in study groups, online for nine weeks before they completed the course by working practically with video filming and editing for two days and for a one-day presentation of the final course assignment.

The course used social software, blogs and podcasts, integrated into the course design. The intention was to learn how to use these resources. The course also had in its design an online approach, with course delivery and course interaction organised around a course website working as a LMS where all course information, study guide, links, etc. 
were presented. The different social software was integrated on the website, and students were required to use these as learning resources throughout the course.

There were several assignments in the course, and students worked both individually with some of the assignments and in study groups with others. Each student wrote an individual paper on ICT and media as tools in their pedagogical practices. Individual work was also conducted with an assignment concerned with planning, creating and publishing material on the web. Students worked both individually and collaboratively. They accessed podcasts of lectures through their $i$ Pods $/ \mathrm{mp} 3$ players, and they made individual comments on lectures in the blogs. They then commented upon the blogs of each other and on different understandings of lectures. Students had access to the podcasts at any time convenient to them, and they then wrote in their blogs about the contents when they had time. Comments upon other student's blogs were made during the time of the course by both students and teachers.

Each study group had the assignment to write a manuscript and a storyboard for a digital video production that was their final task. In the course study guide, all four of these assignments were described and each description of the assignment included a description of the assessment.

In the course study guide, the assessment in the course was described as formative, and since several assignments were of a practical nature, participation in all aspects of the course was mandatory. Also presented were the summative assessment criteria on each assignment, with references to each assignment's requirements. In terms of the teachers' inventions, they were present in the activities starting up and closing the course respectively and in combination with teachers functioning as online facilitators during the weeks in between.

\section{The students' voices}

Based on the course evaluation, this section provides a view of the students' responses in relation to the desired learning outcomes. Using ICT and media as pedagogical tools in the course was a way to make the students aware of the potential of the tools for their own learning and for their own practice. The advantages of using podcasts were, according to the students, that the tool made it possible to recapitulate and return for detailed listening. One student put it: "for those who don't manage to take notes it can be useful with podcasts after the lecture". Listening, and not reading, was often preferred by the students, and podcasts were perceived as a good way to complement campus lectures. As one student formulated it: "Better with a podcast than to read an article, easier to listen". Podcasts were also perceived by the students to enable them to participate in the course in a flexible way. This is expressed by one student as: "Would like to have more lectures as podcasts, so you can access them when and where from you like". Only a few students experienced the use of podcasts as a one-way learning activity, rather the portability and time shifting features of podcasting were appreciated by the students.

A majority of the students also claimed that the use of both blogs and podcasts worked as scaffolds in relation to their learning in the course. Blogs seemed to be especially appreciated. One student said "Excellent, more relaxed than to write an assignment in the traditional way". The students were of the opinion that blogs offered possibilities for sharing thoughts and getting qualified responses from peers, not only from the teachers. As one student put it: "Good that others can comment on what you have 
written and vice versa. Often it is only the teacher assessing what is written". These responses were used by the students to develop their own thinking about a subject matter. This is expressed by one student as: "It made me think about what I had read in the literature". Also interesting to note is that writing for an audience through blogs was said to make the students more focused in their writings and that they tried harder in order to create interesting and thoughtful postings and comments.

One important aspect was that the use of blogs both made possible an experience with a new digital tool for learning and a providing of ideas about its use as a learning tool in their own teaching practices. Using a blog, one student reasoned, can help in the school by: "letting the pupils practise on reading and writing, and to communicate with the parents". The students sometimes experienced a disadvantage communicating through blogs, as they found it harder to interpret the intended message compared to face to face interaction. Another drawback was that public forums now and then can lead to performance anxiety. To summarise, it seems that a majority of the students both benefitted in the course from the active use of ICT and media, and made meaning of ICT and media as pedagogical tools for their own use.

\section{Analysis - signs for learning?}

This section will present interpretations of the signs as they can be understood in the conditions for the students' meaning-making process. Beginning with the institutional norms and values in the course study guide, they can be interpreted to reflect a view of learning as both an individual and cognitive process, and a social and collective process. Even though students are assessed and graded on an individual basis, a largee amount of course work is expected to be carried out collectively through collaboration in the LMS, in an OLC oriented practice.

There are two things that are noticeable in the course design in relation to assessment issues and in relation to a social process of learning. First, there is the amount of student centeredness that is included in the design by the use of the digital environment of the web. Students have access to course material twenty-four hours a day, seven days a week, and can be in control of their learning process. Second, there is the amount of work that is required of each student in collaboration with others. The students have to rely on others in order to achieve grades and pass exams. By letting the students control when and how their collaborative work should be organised, the course design has a social process of negotiation built into it. By stating the course requirements in terms of assessment at the same time as the assignments are presented and introduced, the performance of each student is aligned with the examination and assessment practice of the course early on. The students are thereby directed both at their own learning and towards their peers, and they have to balance their individual concerns with those of others. Student-centred learning points out the relationship between teaching, learning and assessment and links between the design, delivery and assessment of student learning.

The intentions behind the students' meaning-making processes as they are framed by the course design can also be interpreted as ambiguous. The students have to master the web as a learning environment based on delivery and content at one level, and at another level, they are intended to develop abilities to plan for and to publish content of their own. That is, they are intended to first have the skills to access the web, and then to develop the skills to perform on their own on the web. The same ambiguity is present in the individual and group-related assignments. Students must first be able to 
use the podcasts and access the material in a process of individual learning, and then learn how to use the blog tool to express both their own learning and comment upon and learn from others. Both these examples are guided in the course design by the assessment criteria and assessment practice. Students are taught to direct their learning with a starting point in the learning outcomes of the course, and to work individually and with peers towards the performance of the required objectives and aims. The course is designed to support learning such as it is stated in the learning outcomes, and students are taught to perform together with others in accordance with these aims. The design appears to be built on the assumption that the student on an individual level already know how to use ICT and media, and that the process emphasised in the design is to learn how to perform in the digital environment. Design for active participation is in fact a question of a design that teaches the students how to teach each other how to perform successfully in an educational context framed by precisely the practice of assessment, formatively and summatively.

If taking the above reasoning in relation to the voices of the students, the design of the course, its assessment practices, and the in-built social software, podcasts and blogs seemed to have functioned rather well. It could be that the students already from the start of the course had certain competencies to master the content and related learning activities, or at least they developed those quickly through their participation. Furthermore it can be said that they performed in a knowledgeable way in relation to how to balance their individual concerns with those of others, an ability to switch between individual and collaborative learning process. Indeed a majority of the students actually expressed in the evaluations that the use of blogs, podcasts and social software in combination with the design of the course supported their learning and cultivated processes characterised by dialogue, reflection and meaning-making. In other words the design of the course, including its assessment of assignments, helped the students to reach the desired learning outcomes as they were formulated by the teachers of the course.

A possible conclusion is therefore that the students were framed by the design in a way that supported their learning process and helped them towards the intended meaning-making of ICT and media as it was expressed in the learning outcomes of the course.

\section{Discussion}

In relation to the Bologna process and the use of active verbs in the learning outcomes, today's theoretical and empirical arguments for focusing the social dimension when it comes to learning, participating and assessment in online and offline higher education are valuable. The theoretical development of OLC, the construction of a participationdriven Web 2.0 together with the evolution of social software is equally valuable for online higher education based in the idea of student centredness. Together, it seems to sketch a picture of the active student, learning collaboratively with other students in a social context situated in an online environment and who, through shared negotiating of meaning and with mutual engagement (Wenger, 1998) construct knowledge of the content matter. As students are involved in the assessment practice through formative assessment procedures, commenting on each other's work and helping each other, they become part of the process of formatting the knowledge and learning on how to perform with their peers. Their belonging to a community of peers is fostered and directed in its scope by the assessment practices. 
Such a picture is rather promising and progressive in its kind. It opens up for several innovative ideas of how to take advantage of the participation-driven Web 2.0 when designing for learning in online higher education. It further seems to greatly change the practice of assessment, and to provide the university teachers with rich opportunities to design for an assessment process characterised by a high amount of student involvement throughout this process. A related question that, though, that needs to be addressed in further research is the values embedded in the design, underpinning the process of learning from peers.

The use of the designs for learning, the formal learning sequence model (Selander, 2008), provides a possibility to point towards the importance of using a course design in an informed way for learning outcomes. That is, a course design that is based on a view of learning not only individual and cognitive, and although course design can be largely based on student centeredness, there are great possibilities for teachers to plan for and design a social meaning-making process. In addition, in order for students to learn, one must stress the importance of the teachers' knowledge of course designs as well as knowledge of ethical issues. Although the Bologna process has as one of its core values student centeredness, it might be highly problematic to strive for those goals without a course design built by professional teachers competent within their field of expertise and with a clear ethical standpoint.

Analysing this particular case, quite a few questions have emerged. Questions that have risen are for example, is participation and learning always possible to design, and will the students in fact let themselves be designed to participate as easily as the learning sequence model might let us to assume? Or will their meaning-making processes disregard the second transformational cycle, once their first representations of the course content have been established? Is the format of formal learning, i.e. schooling, so highly framed by its assessment practices as can be assumed by previous research on assessment, that signs for learning in a course, such as the one reported on in this article, are guiding the meaning-making process of the students to the degree where meaning-making (and learning) is designed and the student performance is in accordance with the course design? Or is the meaning that the students make in a course something quite different than what is expected, perhaps learning to perform within a digital environment in unexpected ways? Or maybe, the notion of online higher education as a participation-driven Web 2.0, and student centred learning through the use of social software and OLCs just becomes a question of ideology that may in fact operate through a strong notion of (traditional) control by means of assessment?

To conclude, data from the evaluation suggest some answers to these questions, but not all of them. The design of an online higher education course such as the one reported upon in this article may help important educational and learning processes, for example collaboration, reflection and meaning-making. Nonetheless, we would like to point at the necessity for university teachers, educational technologists and others to continuously reflect upon the practice of assessment when designing for learning. To continuously ask whether or not the design for active participation teaches students how to represent and perform successfully in an educational context framed by the practice of assessment and to reflect upon what this means in a context of learning from peers? Maybe then a deeper insight into these questions can be gained; designing online higher education courses in an informed way and thereby enhancing student centred learning orchestrated by a formative and process oriented assessment. 


\section{References}

Alexander, B. (2006). Web 2.0: A new wave of innovation for teaching and learning? EDUCAUSE, 41(2), 32-44. http:/ / www.educause.edu/EDUCAUSE+Review/EDUCAUSE ReviewMagazineVolume41/Web20ANewWaveofInnovationforTe/ 158042

Balacheff, N., Ludvigsen, S., de Jong, T., Lazonder, A. \& Barnes, S. (Eds.) (2009). Technologyenhanced learning. Principles and products. Milton Keynes: Springer.

Beldarrain, Y. (2006). Distance education trends: Integrating new technologies to foster student interaction and collaboration. Distance Education, 27(2), 139-153.

Black, P. \& William, D. (1998). Assessment and classroom learning. Assessment in Education: Principles, Policy E Practice, 5(1), 7-74.

Bloxham, S. \& West, A. (2004). Understanding the rules of the game: Marking peer assessment as a medium for developing students' conceptions of assessment. Assessment $\mathcal{E}$ Evaluation in Higher Education, 29(6), 721-733.

Bologna Working Group on Qualifications Frameworks (2004). Report on a framework for qualifications of the European higher education area. [viewed 23 Sep 2009, verified 18 Dec 2010] http:/ / www.jointquality.nl/content/ierland/draft_report_qualification_framework_EHEA2.pdf

Boyle, A. (2007). The formative use of e-assessment: Some early implementations, and suggestions for how we might move on. In Proceedings of the 11th International Computer Assisted Assessment (CAA) Conference. [viewed 10 Aug 2009]. http:/ / www.caaconference. com/pastConferences / 2007 / proceedings / Boyle $\% 20$ A\%20b1_formatted.pdf

Boyle, A. \& Hutchison, D. (2009). Sophisticated tasks in e-assessment: What are they and what are their benefits? Assessment \& Evaluation in Higher Education, 34(3), 305-319.

Challis, D. (2005). Committing to quality learning through adaptive online assessment. Assessment E Evaluation in Higher Education, 30(5), 519-527.

Davies, J. \& Merchant, G. (2009). Web 2.0 for school, learning and social participation. New York: Peter Lang.

Dillenbourg, P., Baker, M. Blaye, A. \& O'Malley, C. (1995). The evolution of research on collaborative learning. In P. Reimann \& H. Spada (Eds.), Learning in humans and machines: Towards an interdisciplinary learning science (pp. 189-211). Oxford: Elsevier.

Elwood, J. \& Klenowski, V. (2002). Creating communities of shared practice: The challenges of assessment use in learning and teaching. Assessment \& Evaluation in Higher Education, 27(3), 243-256.

Friesen, N. (2009). Re-thinking e-learning research: Foundations, methods, and practices. New York: Peter Lang Publishing.

Gadamer, H.-G. (1989). Truth and method. London: Sheed and Ward.

Gibbs, G. \& Simpson, C. (2004-05). Conditions under which assessment supports students' learning. Learning and Teaching in Higher Education, 1, 3-31.

Harasim, L. (2002). What makes online learning communities successful? In C. Vrasidas \& G.V. Glass (Eds.), Distance education and distributed learning (pp. 181-200). Greenwich, CT: Information Age Publishing. 
Hrastinski, S. (2007). Participating in synchronous online education. (unpublished doctoral thesis). Lund: Sweden. [verified 19 Dec 2010] http:/ / lup.lub.lu.se/luur/download?func=download File\&recordOId $=599311 \&$ fileOId $=600490$

JISC (The Joint Information Systems Committee) (2007). Effective practice with e-assessment: An overview of technologies, policies and practice in further and higher education. [viewed 10 Aug 2009]. http:/ / www.jisc.ac.uk/media/documents/themes/elearning/effpraceassess.pdf

Jonassen, D. H. (2002). Learning to solve problems online. In C. Vrasidas \& G.V. Glass (Eds.), Distance education and distributed learning (pp. 75-98). Greenwich, CT: Information Age Publishing.

Jonassen, D. H. \& Land, S. M. (Eds.). (2000). Theoretical foundations of learning environments. Mahwah, NJ: Lawrence Erlbaum Associates.

Lindberg, J. O. \& Olofsson, A. D. (2008). OLC in the context of the Other: Face, trace and cyberspace. International Journal of Web Based Communities, 4(2), 188-198.

Lindberg, J. O. \& Olofsson, A. D. (Eds.) (2010). Online learning communities and teacher professional development: Methods for improved education delivery. Hershey, Pennsylvania: IGI Global.

O’Donovan, B., Price, M. \& Rust, C. (2004). Know what I mean? Enhancing student understanding of assessment standards and criteria. Assessment $\mathcal{E}$ Evaluation in Higher Education, 9(3), 325-335.

Olofsson, A. D. \& Lindberg, O. J. (2006). Whatever happened to the social dimension? Aspects of learning in a distance-based teacher education programme. Education and Information Technologies, 11(1), 7-20.

Olofsson, A. D. \& Lindberg, O. J. (2007). Enhancing phronesis: Bridging communities through technology. In L. Tomei (Ed.), Online and distance learning: Concepts, methodologies, tools, and applications (6-volume set) (pp 3157-3175). Hershey, PA: Information Science Reference.

Olofsson, A. D. \& Lindberg, J. O. (Eds.) (2011). Informed design of educational technologies in higher education: Enhanced teaching and learning. Hershey, Pennsylvania: IGI Global.

Olofsson, A. D. \& Lindberg, J. O. \& Stödberg, U. (2011). Shared video media and blogging online. Educational technologies for enhancing formative e-assessment? Campus Wide Information Systems, 28(1), 41-55.

O'Reilly, T. (2005). What is web 2.0? [viewed 27 Jan 2008]. http: / / www.oreillynet.com/pub/a/oreilly/tim/news/2005/09/30/ what-is-web-20.html

Palloff, R. M. \& Pratt, K. (2005). Collaboration online: Learning together in community. San Francisco, CA: Jossey-Bass.

Paulsen, M. F. (2003). Online education: Learning management system: Global e-learning in a Scandinavian perspective. Bekkestua, Norway: NKI Forlaget.

Porter, D. (2006). Innovations, trends, and creativity in distance learning. Using the social fabric of the web as a strategic lens to monitor trends and innovations. Paper presented at the 4th International Congress on Education and Technology - Inter-American University of Puerto Rico (UIPR), Puerto Rico, 7 September. [verified 19 Dec 2010] http: / / citeseerx.ist.psu.edu / viewdoc/ download?doi=10.1.1.84.9530\&rep=rep1\&type=pdf

Price, M. (2005). Assessment standards: The role of communities of practice and the scholarship of assessment. Assessment \& Evaluation in Higher Education, 30(3), 215-230. 
Price, M., O'Donovan, B. \& Rust, C. (2007). Putting a social-constructivist assessment process model into practice: Building the feedback loop into the assessment process through peer review. Innovations in Education and Teaching International, 44(2), 143-152.

Rasmusson, M., Sundgren, M. \& Sahlin, S. (2008). Podcasting and blogging - the way to learn? Presented at the European Conference on Educational Research 2008, Gothenburg, 10 September. [verified 19 Dec 2010] http: / / www.eera-ecer.eu/ecer-programmes / conference/ ecer-2008/ contribution / 895/ ?no_cache=1\&cHash=9cf99997f1\&type=123

Reigeluth, C. M. (Ed.). (1999). Instructional-design theories and models, volume II. A new paradigm of instructional theory. Mahwah, NJ: Lawrence Erlbaum.

Rowntree, D. (1977). Assessing students: How shall we know them? London: Harper \& Row, Publishers.

Rust, C., O’Donovan, B. \& Price, M. (2005). A social constructivist assessment process model: How the research literature shows us this could be best practice. Assessment $\mathcal{E}$ Evaluation in Higher Education, 30(3), 231-240.

Sambell, K., McDowell, L. \& Brown, S. (1997). ‘But is it fair?': An exploratory study of student perceptions of the consequential validity of assessment. Studies in Educational Evaluation, 23(4), 349-371.

Selander, S. (2008). Tecken för lärande - tecken på lärande. Ett designteoretiskt perspektiv [Signs for learning - signs of learning. A design theoretical perspective]. In A.-L. Rotsvall \& S. Selander (Eds.), Design För Lärande [Design for learning] (pp. 28-44). Stockholm: Nordstedts Akademiska Förlag.

Sergiovanni, T. (1999). The story of community. In J. Retallick, B. Cocklin \& K. Coombe (Eds.), Learning communities in education (pp. 9-25). London: Routledge.

Sieber, J. E. (2005). Misconceptions and realities about teaching online. Science and Engineering Ethics, 11(3), 329-340.

Sinclair, G., McClaren, M. \& Griffin, M. J. (2006). E-learning and beyond. Paper prepared as part of the Campus 2020 process for the British Columbia Ministry of Advanced Education. Vancouver, August. [verified 19 Dec 2010; $3.6 \mathrm{MB}$ ]

http: / / www.llbc.leg.bc.ca / public/ pubdocs / bcdocs / 405566/ elearningaug15.pdf

Snyder, B. R. (1971). The hidden curriculum. New York: Alfred A. Knopf, Inc.

Sorensen, E. K., \& Ó Murchú, D. (Eds.). (2006). Enhancing learning through technology. Hershey, PA: Idea Group Inc.

Stake, R. E. (1995). The art of doing case study research. London: SAGE Publications.

Struyven, K., Dochy, F. \& Janssens, S. (2005). Students' perceptions about evaluation and assessment in higher education: A review. Assessment $\mathcal{E}$ Evaluation in Higher Education, 30(4), 331-347.

Swedish National Agency for Higher Education (2008). E-learning quality. Aspects and criteria for evaluation of e-learning in higher education. Stockholm: Åtta.45 Tryckeri AB. [verified $19 \mathrm{Dec}$ 2010] http:/ / www.hsv.se / download/18.8f0e4c9119e2b4a60c800028057/ 0811R.pdf

Van den Bergh, V., Mortelmans, D., Spooren, P., Van Petegem, P., Gijbels, D. \& Vanthourmout, G. (2006). New assessment modes within project-based education - the stakeholders. Studies In Educational Evaluation, 32(4), 345-368. 
Vattimo, G. (1997). Beyond interpretation: The meaning of hermeneutics for philosophy. Stanford, CA: Stanford University.

Vygotsky, L. (1962). Thought and language. Cambridge, MA: MIT Press.

Vygotsky, L. (1978). Mind in society: The development of higher psychological processes. Cambridge, MA: Harvard University Press.

Wenger, E. (1998). Community of practice: Learning, meaning and identity. Cambridge, MA: Cambridge University Press.

Williams, P. (2008). Assessing context-based learning: Not only rigorous but also relevant. Assessment E Evaluation in Higher Education, 33(4), 395-408.

Willis, J. W. (Ed.). (2009). Constructivist instructional design (C-ID): Foundations, models, and examples. Charlotte, North Carolina: Information Age Publishing.

Yin, R. K. (2003). Case study research: Design and methods. (3rd ed.). Thousand Oaks, CA: Sage.

Zumbach, J., Schwartz, N., Seufert, T. \& Kesters, L. (Eds.). (2008). Beyond knowledge: The legacy of competence. Milton Keynes: Springer.

Dr J. Ola Lindberg, PhD, Senior Lecturer

Department of Education, Mid-Sweden University, Härnösand, Sweden.

Email: ola.lindberg@miun.se Web: http: / / www.pedag.umu.se/om-

institutionen / personal / visa-person/?uid=olalig97

Dr Anders D. Olofsson, $P h D$, Associate Professor

Department of Education, Umeå University, Umeå, Sweden.

Email: anders.d.olofsson@pedag.umu.se

Web: http: / / www.pedag.umu.se/om-institutionen/personal/olofsson-d-anders

Mr Ulf Stödberg, PhD (Candidate), MA by Research and Thesis

Department of Education, Umeå University, Umeå, Sweden.

Email: ulf.stodberg@pedag.umu.se Web: http:/ / www.pedag.umu.se/om-

institutionen / personal / visa-person / ?uid=ulfstg99 